\title{
OLYMPIC EDUCATION IN THE PREPARATION OF THE VOLUNTEERS OF INTERNATIONAL SPORTS COMPETITIONS
}

\author{
Iryna Boiko
}

\begin{abstract}
Аннотация. Обоснована целесообразность включения вопросов олимпийского образования в процесс подготовки волонтеров международных спортивных соревнований. Установлено, что олимпийское образование, целью которого является приобщение различных слоев населения к идеалам и ценностям олимпизма, является важным аспектом в развитии современного олимпийского движения. Определено, что организаторам крупных спортивных соревнований, фрестивалей, праздников целесообразно обратить внимание на включение вопросов, связанных с олимпийским образованием, в процесс подготовки волонтеров, которые будут помогать в проведении данных мероприятий.

Ключевые слова: Олимпийские игры, олимпийское образование, волонтеры, спортивные волонтеры, олимпийские волонтеры.

Анотація. Обгрунтовано доцільність включення питань олімпійської освіти у процес підготовки волонтерів міжнародних спортивних змагань. Встановлено, що олімпійська освіта, метою якої є прилучення різних верств населення до ідеалів і цінностей олімпізму, - важливий аспект у розвитку сучасного олімпійського руху. Зазначено, що організаторам великих спортивних змагань, фестивалів, свят доцільно звернути увагу на включення питань, пов'язаних з олімпійською освітою, у процес підготовки волонтерів, які будуть допомагати в проведенні даних заходів.
\end{abstract}

Ключові слова: Олімпійські ігри, олімпійська освіта, волонтери, спортивні волонтери, олімпійські волонтери.

Definition of the problem. Analysis of recent research and publications. The problem of finding new forms of humanization is relevant to current social and cultural situation. The Olympic Movement is based on the ideals and values of Olympism. Olympism is the largest social phenomenon of the modern era, covering the international community in a spirit of peaceful competition, fair, open struggle without any discrimination. These values underpin the proven viability of educational, humanitarian and educational potential. Humanity is considered as one of the most important human values. One of the most useful means of attracting a diverse community to the ideals and values that form the basis of the Olympic Movement is improvement and implementation of Olympic education into modern society. Becoming more familiar social phenomena, which based on humanity, love for one's neighbour and the recognition of each, without exception, is one of a person's human right. Among them, the global nature of volunteering acquires and Olympism. Volunteer movement is humanistic enterprise which aims to help all those who need it, and based on the principle of charity, without salary, promotion, for the welfare and prosperity of communities and society as a whole [6, 11].

We need to take into consideration that volunteers are active in sports and the Olympic movement that's why particular attention is required to the implementation of Olympic education in the process of their training [7, 9]. But, unfortunately, nowadays the volunteers mainly come to see the event and competitions themselves, not to become a part of the organizing team. In this case, it is essential to evaluate the main steps and peculiarities of the training process for volunteers for the international megasporting event. The vast majority of volunteers fulfill their roles without incident and with dedication to their duties and commitment to the customers.

Analysis of the scientific research, dedicated to the implementation of Olympic education in training volunteers for sporting events, define that there are duties that justify the social importance of the Olympic Movement. However, the issue of implementation of Olympic education in the process of training volunteers remains a less explored scientific problem. The practical significance of the research is to transform theoretical and empirical knowledge in relevant areas of deepening integration processes of Olympic education in training volunteers in the development of modern sports movement.

Relationship of academic programs or practical tasks. The research was conducted under the topic 0111U001714 «Historical, organizational, methodological and legal basis of implementation of Olympic education in Ukraine», which is developed according to the order of the Ministry of Education and Science of Ukraine № 1241 from 28.10.11 year.

The purpose of the work is to justify the feasibility of integration of Olympic education in the pro- 
cess of training of volunteers for international sports competitions.

Methods: analysis of literature, documentary materials, historical, survey methods comparison and matching of materials, methods of mathematical statistics.

Results of the study. To be a volunteer means sympathy for the people; in common sense that means flexibility, practical ingenuity, ability to work in a team, sequence, and reliability.

These are qualities that a sports volunteer should have and that comply with the philosophy of Olympism. Olympism is a concept that has its origins in ancient Greece and contains the fundamental principles of educational rights. Olympic education aims to involve children and young people to the ideals and values of Olympism [5]. Olympism is a philosophy of life, which brings together balanced and united qualities of body and spirit, the concept of harmonious educational development of human being by means of sport, as well as the spread of humanistic ideas in society [1], cooperation, mutual understanding and cooperation. The leading philosophical conceptual ideas of Olympism include:

- the idea of peace, peaceful coexistence of social systems, states, and people;

- the idea of universal values of Olympism, which is based on internationalism, intersocietal education;

- the idea of a humanistic, all-round development of personality, which is the basis of the Olympic education of youth, Olympic subculture;

- the idea of the priority of moral values in the Olympism, based on the philosophy of FairPlay [4, 12].

The main tasks of the Olympic education are:

- the formation of children and youth around the world, on the basis of patriotism, morality, lawabiding, healthy way of life;

- development of a motivation to learn, to work and to create a positive attitude to life;

- to enforce the concept of duties and responsibilities;

- the harmonious development of adolescents based on individual capabilities;

- enhancing the role of Olympic values in everyday life.Olympic education is the specially organized multi-level pedagogical process of formation through the interests, needs and values of Olympism, and it is an integral part of general education [3].

The aim of Olympic education is to create conditions for the formation of complex qualities, attitudes, beliefs, which provide a comprehensive, and harmonious personality development of children, adolescents, and youth. Olympic education is based on the ideas of Olympism. [4]:

The primary functions of Olympic education are

- status (understanding and acceptance of leaders in the fields of education and sports, teachers and athletes in the social role of the Olympic Movement, as an effective means of training young people);

- forming (providing continuing education to teachers and members of educational institutions about the ideas of Olympism);

- information (Influence on the growth of pedagogical skills);

- motivation (Create conditions that encourage actors in Olympic education carrying out efficiently their duties and functions);

- -prevention (forecasting, averting, and elimination of negative behavior, negative qualities and traits of children and adolescents).

The highest reward for Olympic volunteers is that the objecives and the success of the Games will be achieved. In additional to this ideal reward, there are also other material awards; for example, to receive tickets, a special medal or a certificate [1]. While volunteers do not receive money for volunteering, the economic value may be costly. At the 2000 Olympic Games, volunteers received two shirts, two trousers, a bag, a raincoat, and a cap. It was about 200 US dollars [2].

At the 2002 Olympic Games volunteers uniform included a jacket, a vest, trousers, a woolen pullover, a cap, a scarf, leather gloves and a bag. It cost about 1000 US dollars of the USA.

The first attempts to integrate education with the modern Olympic Movement took place in the II Olympic Congress in Havre (1897). This education was called by the IOC for studying and discussion of problems of hygiene, pedagogics, history of the physical exercises and other scientific disciplines directly related to physical training and sport. The Olympic education gradually gets more and more important. Article 31 of the Olympic Charter notes that National Olympic Committees have to propagandize at the national level the fundamental principles of Olympism and to promote the distribution of Olympism in training programs at schools and higher educational institutions [10].

The starting point for reforming Olympic education was the XII anniversary of the Olympic Congress in Paris (1994). In the final document the Congress is told: «All members of the Olympic Movement are recommended to combine efforts in an intensification of ethical, cultural and educational values of Olympism, and also expansion of the sphere of sport» $[4,8]$. The main goal and realization of Olympic education is formation of the person who in the actions and thoughts within sports and sports activity and in everyday life is guided by universal humanistic standards of behavior, cultivates 
Olympism and the principles of the Olympic Charter as result. Consequently, the work of volunteers is closely connected with all works for holding the Olympic Games. The number of the attracted volunteers for holding mega sports events such as Olympic Games and the Winter Olympic Games is constantly increasing (see fig. 1). Also, every year the importance of the Olympic Games increases. It's helping to attract more volunteers from all over the world for help in the organization of the Olympic Games. The Organizing Committee of the Olympic Games annually tries to make more and more impressions from the staging, design of Olympic venues, and number of the staff and volunteers.

We can note that activation of the implementation of the Olympic education programs happens, first of all, in those countries that won the right of holding the Olympic Games. In 1976 in Canada, in a year of holding of the XXI Olympic Games, the first program was developed. In 1980 holding the XXII Olympic Games in Moscow became a starting point of the formation system of the Olympic education in Russia. In 1984, when XXIII Olympic Games in Los Angeles took place, there was a program of the Olympic education in the USA. In 2000 the Olympic Games in Sydney became the impetus for the creation of the national program of the Olympic education in Australia: the «Dream Tour». The Olympic Games in Athens (2004) induced Greece for the creation of the comprehensive program of development of the Olympic education in the country «Athens-2004». In China, which held the Olympic Games in 2008 - «The program of the Olympic education «Beijing-2008» was developed and successfully introduced.

\section{Recommendations for the Future}

These recommendations revisit the research objectives. Recommendations for the future are based on knowledge and insights gained in this research both from the literature and interviews. These recommendations are also based on the combined knowledge of the literature, sound practices in place by the researched organizations as well as additional innovative ideas.

In accordance with the results of research the priority directions of the Olympic education and volunteer movement integration around the world were defined. Recommendations include:

- to introduce constantly operating training courses, seminars (full-day, correspondence or remote) of the Center for volunteers training of the NOCs on the basis of the professional higher educational institutions;

- to provide studying of the «Sports and Olympic Volunteering» subject in the Olympic subject area of training programs on physical culture for schools and higher educational institutions;
Figure 1 - Number of volunteers at the Olympic Games

\begin{tabular}{|l|c|l|c|}
\hline Summer Olympics & $\begin{array}{c}\text { Number of } \\
\text { volunteers }\end{array}$ & Winter Olympics & $\begin{array}{c}\text { Number of } \\
\text { volunteers }\end{array}$ \\
\hline Los Angeles, 1984 & 28.742 & Sarajevo, 1984 & 10.450 \\
\hline Seul, 1988 & 27.221 & Calgary, 1988 & 9.498 \\
\hline Barselona, 1992 & 34.548 & Albertville, 1992 & 8.647 \\
\hline Atlanta, 1996 & 47.466 & Lillehammer, 1994 & 9.054 \\
\hline Sydney, 2000 & 46.967 & Nagano, 1998 & 32.000 \\
\hline Athens, 2004 & 45.000 & Salt Lake City, 2002 & 22.000 \\
\hline Beijing, 2008 & 100.000 & Turin, 2006 & 18.000 \\
\hline London, 2012 & 60.000 & Vancouver, 2010 & 29.500 \\
\hline $\begin{array}{l}\text { Rio de Janeiro, } \\
\text { 2016 }\end{array}$ & 70.000 & Sochi, 2014 & 25.000 \\
\hline
\end{tabular}

- to explain the questions of sports volunteering in didactic materials editions of the Olympic Academies, textbooks on physical culture for higher educational institutions and comprehensive schools, textbooks on the Olympic Sport for higher educational institutions profile;

- to search the problems of sports volunteering at the special research institutes and the highest professional educational institutions;

- to promote the volunteer movement in mass media, while carrying out sporting activities of NOCs and Olympic Academies;

- to establish relations with Olympic Academies and the local and regional public volunteer organizations for rendering the educational and methodical help with volunteers Olympic education;

- to implement the practice of sports volunteers involvement in other directions of the voluntary help.

\section{Conclusions}

1. The literature review testifies about the relevance of introduction of the system Olympic education as means of training of volunteers. The subject of research is caused by that the volunteer movement and volunteering, in general, as well as Olympism that arose at the time of Antique Greece. Throughout many centuries, the Olymic Games experienced various transformations and became one of the most large-scale phenomena in a humanization of the world community. Their harmonious integration promotes to increase effectiveness of the penetration process of humanistic ideals and values in public and private everyday life of youth that forms our future. Objective studying and generalization of materials showed about need of the use of Olympic education as means of distribution of the volunteer movement. Also formations of the real behavior of volunteers, lifestyle according to humanistic ideals and values of youth, considering the popularity and mass character of the sport of wide versts of the population.

2. Generalization of humanistic basis of volunteering and the Olympic Education showed existence 
of a quantity of common characteristics in historical and substantive aspects. Volunteering and Olympism are considered as educational and spiritual heritage of the Ancient world. With historical development of mankind ideals and values of humanity were transformed. The second half of the XIX century to the beginning of the XX century became the conclusive phase of centuries-old process of revival in new historical conditions of these two unique phenomena. In the XX centuries, they turned into the permanent world process of the supremacy of humanism.

3. Analysis of references testifies about relevance of integration of the volunteer movement and Olympic Education in educational process of different institutions and also allows to allocate the main tasks of the Olympic education, among which: formation at youth and wide versts of the population of outlook, lack of any manifestation of discrimination which basis is: patriotism, morality, law-abidingness, healthy way of life; formation of positive motivation to study, work, the creative relation to the duties; harmonious development of the person taking into account individual opportunities; increase of a role of the Olympic education in everyday life.

4. Volunteering and Olympism are immediately interconnected with culture and education, directed on creation of the way of life which is based on the educational value of a good example and the respect for general basic ethical principles. The purpose of the volunteer movement and Olympic education is assistance to the harmonious development of the person, to the creation of the world society, caring for the preservation of human dignity. They represent the concentrated, organized, universal and continuous activity of different people and organizations, which inspire humanistic values, mutual understanding, friendship, solidarity. The Volunteer Movement and Olympic Movement are incompatible with any form of discrimination against to the country or gender identity, racial, religious, political character. Volunteering and the Olympic education form the tolerant attitude towards another, skills of participation in socially important activity. Their harmonious combination will promote the increase of consequentialism of a process of penetration of humanistic ideals and values in public and private everyday life of people.

5 . To the priority directions of integration of the Olympic education and volunteer movement belong introduction of continuous training in the Training Center of volunteers; studying of the sports and Olympic Movement within the Olympic Education; publications of questions of sports volunteering in editions Olympic educations, physical culture and sport; carrying out researches on problems of sports volunteering; promotion of the volunteer movement; establish connections of the Olympic Academy with the volunteer organizations; involvement of sport volunteers in other directions of the voluntary help.

Prospects for further research. Further research will focus on the integration of Olympic education in the training program of volunteers.

\section{Literature}

1. Andrew J. Motivations and expectations of volunteers involved in a large scale sports event: A pilot study / J. Andrew // Australian Leisure. - 1996. - P. 21-25.

2. Brettell D. The Sydney volunteers / D. Brettell // Olympic Review, December-January. - 2001. - Vol. XXVII, N 42. - P. 37-43.

3. Brownlie J. Programs and Activities for Olympic education in school / J. Brownlie // Materials Internat. Forum «Youth-Science-Olympism». - 1998. - P. 290.

4. Bulatova M. Ukranian Olympic Academy (1991-2011) / M. Bulatova, V. Ermolova, L. Radchenko. - Kiev, 2011. - $112 \mathrm{p}$.

5. Harrison D. A. Volunteer motivation and attendance decisions: Competitive theory testing in multiple samples from a homeless shelter / D. A. Harrison // J. of Appl. Psychology. - 1990. - 80(3). - P. 371-385.

6. Koreneva M. Fenomen of volunteering in public life and the Olympic Movement: (historical aspect) / M. Koreneva // Krasnodar. - 2008. - 45 p.

7. Rogge J. Volunteerism / J. Rogge // Olympic Review, December-January. - 2001. - Vol. XXVII, N 42. - P. 3.

8. Coordinating Committee for International Voluntary Service [Electronic resource]. - Access mode: http:// ccivs.org.

9. Lanzoni I. The Volunteers during and after the Olympic Games: Youth Camp and Olympic Education School Programmes from [Electronic resource]. - Access mode: http://olympicstudies.uab.es/volunteers/lanzoni.html.

10. Olympic Charter [Electronic resource]. - Access mode: https://stillmed.olympic.org/media/Document\%20 Library/OlympicOrg/General/EN-Olympic-Charter.pdf\#_ga=1.36861216.165904975.1444640186.

11. Volunteering: European experience [Electronic resource]. - Access mode: http://gurt.org.ua/news/ recent/17380.

12. Volunteers of «Sochi 2014» [Electronic resource]. - Access mode: vol.sochi2014.com. 